\title{
Profile of Human TERT and P73 in Oral Squamous Cell Carcinoma Cell Lines Compared to Normal Human Oral Mucosa: a Preliminary Study
}

\author{
Ambar Kusuma Astuti, Irfan Prasetyo, Justisia Nafsi Yunita, Yuniardini Septorini \\ Wimardhani, Febrina Rahmayanti
}

Department of Oral Medicine, Faculty of Dentistry, Universitas Indonesia, Jakarta 10430, Indonesia

Correspondence e-mail to: aka.arkasti@gmail.com

\begin{abstract}
Genetic alteration on p53 allows cellular immortalization and predisposes cells to neoplastic transformation. This immortalization is related to telomere length maintenance by telomerase. Human TERT is a key component of telomerase, which activity is suppressed by $\mathrm{p} 53$. The $\mathrm{p} 73$, the homolog of $\mathrm{p} 53$, has a similar ability in tumor suppression. The P73 is expressed at a different level in various cancer cells and normal tissues. Profile of human TERT and P73 in mutant p53 OSCC cell line and normal human oral mucosa have not been known. Objective: To observe human TERT and P73 profile in mutant p53 OSCC cell lines and normal human oral mucosa. Methods: The extracted protein of HSC-3 and HSC-4 cell lines and normal mucosal tissues were analyzed with SDS PAGE to detect human TERT and p73 expression based on the molecular weight. Results: The HSC-3 cell line showed thicker band density of P73 compared to its density of HSC-4. Only 50\% of normal oral mucosa tissue showed thick P73 band density. The human TERT band was clearly shown in HSC-3 and HSC-4 cell lines but not in normal oral mucosa. Conclusion: Different profile of human TERT and P73 in OSCC cell lines and normal oral mucosa might be cell-type specific and influenced by the status of p53. Analysis of the role of $\mathrm{p} 73$ in these cancers might need further research to determine possible p 73 substitution for p53 function.
\end{abstract}

\begin{abstract}
ABSTRAK
Profil hTERT dan P73 pada kultur sel kanker mulut dibandingkan mukosa normal: studi pendahuluan. Perubahan genetik pada p53 memungkinkan terjadinya imortalisasi sel dan meningkatkan predisposisi terjadinya transformasi ke arah neoplasma. Hal ini terkait dengan aktivitas telomerase yang menjaga panjang telomer, yang aktivitasnya seharusnya dibatasi oleh p53. p73, yang merupakan homolog p53, mempunyai kemampuan supresi tumor yang mirip dengan p53. Tingkat ekspresi P73 dan human TERT kemungkinan berbeda pada berbagai jenis sel kanker dibandingkan dengan jaringan normalnya. Saat ini belum terdapat data tentang profil protein human TERT dan P73 pada sel lini karsinoma sel skuamosa oral (KSSO) dibandingkan dengan jaringan mukosa oral normal. Tujuan: Studi ini bertujuan untuk mendapatkan profil human TERT dan P73 pada sel lini KSSO dengan mutasi p53 dibandingkan dengan mukosa oral normal. Metode: Sel lini HSC-3 dan HSC-4 dengan mutasi p53 dikultur sedangkan mukosa oral normal dikumpulkan dari pasien tanpa kanker yang menjalani perawatan bedah mulut. Ekstraksi protein dan analisis profil human TERT dan P73 dilakukan dengan SDS-PAGE dan ditentukan berdasarkan perkiraan berat protein. Hasil: Pita human TERT jelas terlihat pada sel HSC-3 dan HSC-4 namun tidak pada mukosa oral normal. Densitas pita P73 pada sel HSC-3 terlihat lebih tebal dibandingkan pada sel HSC-4. Hanya 50\% sampel mukosa oral normal memperlihatkan pita P73. Simpulan: Terlihat profil human TERT dan P73 yang berbeda pada sel kanker dan sel normal. Perbedaan ini kemungkinan bersifat spesifik tergantung jenis sel dan dipengaruhi oleh status p53. Perlu dilakukan penelitian lanjutan untuk menganalisis kemungkinan peran p73 dalam menggantikan fungsi p53 pada kanker mulut selanjutnya diperlukan.
\end{abstract}

Key words: , oral squamous cell carcinoma, P73, hTERT 


\section{INTRODUCTION}

The p53 is the most common tumor suppression gene mutated in oral squamous cell carcinoma (OSCC) with the frequency of $50 \%$ cases. ${ }^{1}$ It functions as activator of transcription process, DNA repair, apoptosis, senescence, cell cycle regulator, and suppress activities of several genes, one of them is $h T E R T .^{1,2}$ The $h T E R T$ encodes 7 protein isoforms, with human TERT acts as the key component that control the activity of telomerase. ${ }^{3,4}$ Telomerase is defined as enzyme that can lengthen DNA by adding telomere repeat at the chromosome ends. ${ }^{5}$ Telomerase presents on most cancer cells. ${ }^{6}$ Several transcription factors, including oncogene and tumor suppressor genes (TSG) could influence the $h T E R T$ transcription. Inactivation of $\mathrm{p} 53$ plays a role in $h T E R T$ activation on carcinogenesis, through the alteration from normal cells with negative telomerase into cancer cells with positive telomerase. $^{7}$

In 1997, the human homolog of p53, called p73 was identified. ${ }^{8}$ The $\mathrm{p} 73$ shares more than $60 \%$ similarities of amino acid as in p53 DNA binding region, including conservation of all DNA contact and structural residues that become the most frequent location of p53 mutation in tumor. ${ }^{9}$ In the other hand, p73 shared 58\% similarities with p53 tetramerization domain and $29 \%$ similarities with $\mathrm{p} 53$ transactivation (TA) domain. ${ }^{9}$ In contrast to $\mathrm{p} 53$, mutation of $\mathrm{p} 73$ only occurred in less than $0.5 \%$ of cancers. ${ }^{10,11}$ Even though $\mathrm{p} 73$ mutation is rare, the expression and function of different $\mathrm{p} 73$ isoforms are clearly altered in certain cancers. The P73 had a complexitivity on its protein isoforms because of the use of alternative promoter and differential mRNA splicing. There are two variants of P73 with a difference at its $\mathrm{N}$ terminus, which comes from the utilization of two different $\mathrm{p} 73$ promoter. ${ }^{12,13}$
Data regarding $\mathrm{p} 73$ mutation has not been available in the literature, however different roles of several isoforms of p73 as tumor suppressor gene with antiapoptosis effect (TAP73) and as oncogene $(\triangle N \mathrm{P} 73)$ have been elucidated. ${ }^{6,7}$ It has also been shown the correlation between tumor stage and the level of p73 expression. Studies on oral cancer have shown tendency of increased telomerase activity that was in concordance with the progression of carcinogenesis. ${ }^{8,9}$ Therefore, changes in the expression pattern of human TERT would be expected. ${ }^{12,13}$ Data showing correlation between p73 expression in tumors with different status of p53 mutation and telomerase activity would be important to give basis for further study that investigate the actual main isoform of $\mathrm{p} 73$ involved.

\section{METHODS}

OSCC cell lines type HSC-3 and HSC-4 were cultured on high glucose DMEM (GIBCO) supplemented with $10 \%$ FBS along with $100 \mathrm{iu} / \mathrm{ml}$ Penicillin Streptomycin (GIBCO) and $2.5 \mu \mathrm{g} / \mathrm{ml}$ Fungizone (GIBCO), then incubated at $37^{\circ} \mathrm{C}, 95 \%$ humidity with $5 \% \mathrm{CO}_{2}$ (Figure 1). After $90 \%$ confluency was reached, the cells were harvested with $0.02 \%$ tryp$\sin / 0.25 \%$ EDTA (JRH Biosciences) and subjected to protein extraction. This study used 4 to 5 culture plates of the HSC-3 and HSC-4 cell lines for analysis of the protein profile.

Fourteen dental patients without HNSCC or other malignancy, who were undergoing minor oral surgery in the Departments of Oral and Maxillofacial Surgery or periodontal surgery in the Faculty's Dental Hospital, gave their approval to participate in the study. Control tissue was obtained from the gingival or adjacent oral mucosa involved in the removal of
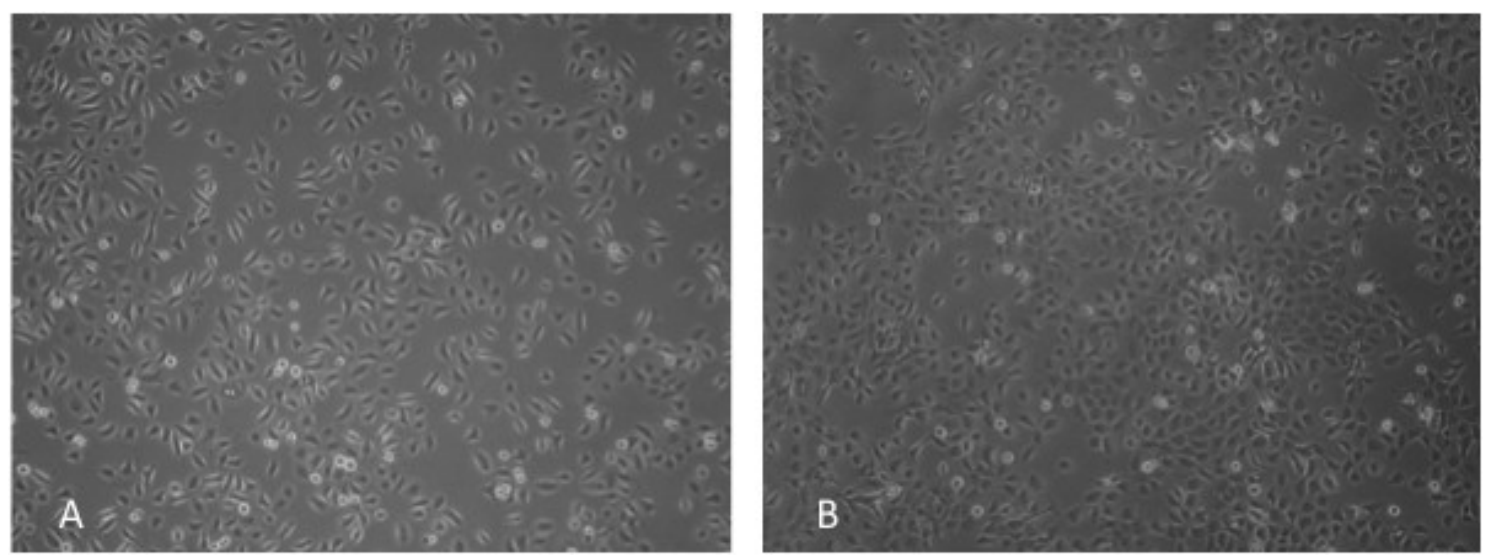

Figure 1. Phase contrast photomicrographs of the HSC-3 cell line (A) and HSC-4 cell line (B) after 2 days culture (Original magnification $\mathrm{x} 10$ ) 
teeth or hyper plastic gingival tissue removed in periodontal surgery. This tissue was further stated as normal human oral mucosa (NHOM) in this study.

Extraction of protein from HSC-3, HSC-4 cell lines, and normal human oral mucosa was performed by using Kit TRIzol (Invitrogen) following instruction from the manufacturer. Bradford Protein Assay was performed to quantify total protein concentration of each sample. Analysis of protein used SDS PAGE to observe the samples protein profiles based on its molecular weights. SeeBluePlus2 (Invitrogen) protein molecular weight marker was used in this study. This marker consists of 10 protein with molecular weight ranged from 3 to $188 \mathrm{kDa}$. The gels obtained was stained with $0.05 \%$ Comassie Blue. The protein profiles and shown as dark bands running at a lane within the gels after staining. The resulting protein profiles had molecular weight ranging from 14 to $188 \mathrm{kDa}$.

The gels were further analysed for semi quantitative assessment of bands intensity using Gel Doc 2000 with Quantity One (BioRad) program. The gels were captured with white light mode. This mode was used for samples that can reflect and scatter lights. Using this mode, data was measured in uncalibrated optical density (uOD) units. The higher the uOD, the higher the opacity. The gels' ability to reflect the light would be assumed as protein bands with a certain minimal densities. The minimal densities used in this research were based on Quantity One program's initial assembly. The gel's bands in certain sites were compared with protein standard's band to estimate the exact protein molecular weights. ${ }^{21}$ The protein marker used is SeeBluePlus2 (Invitrogen) that has effectively determined molecular weight between 3 to $188 \mathrm{kDa}$ in SDS PAGE.

\section{RESULTS}

The human TERT and P73 expression was presented visually as band with different densities according to the molecular weight marker. There are five visual categories used to grade the protein expression based on protein bands densities. This study categorized the bands to be very thick, medium, thin, and very thin. On SDS PAGE, P73 protein that had $90 \mathrm{kDa}$ molecular weight was estimated to be located between 70 to $117 \mathrm{kDa}$. Meanwhile the hTERT protein that had $127 \mathrm{kDa}$ molecular weight, was estimated to be located between the 117 and $137 \mathrm{kDa}$. After comassie blue staining, the gels were further analyzed using Gel Doc 2000 and Quantity One (BioRad) program was used to determine the more accurate protein samples molecular weight. The data obtained from this program were measured in uncalibrated optical density (uOD) units. The gel's bands in cer- tain sites were compared with protein marker band as a standard to estimate the exact protein molecular weight, so the more accurate protein molecular weight can be detected and compared with visual observation.

This study might have detected the human TERT $(127 \mathrm{kDa})$ estimated to be located between 117 and $137 \mathrm{kDa}$ bands in the gels. Relatively low band intensities of suspected human TERT were showen (Figure 2). The human TERT were detected in 4 repeated samples of HSC-4 cell lines, however density of the bands was not similar between repeated samples (Figure 2A). Similarly, different band densities (ranging from medium to thin density) were also showed in the five repeated samples of HSC-3 cell line (Figure 2B). Thin band of human TERT was shown (Figure 2A) in 2 out of 14 of NHOM samples (Figure 2A). The suspected $\mathrm{P} 73$ was expressed in HSC-3 and HSC-4 cell lines and normal human oral mucosa (Table 1). All repeated samples of HSC-3 cell line showed thick bands of P73 (Figure 2A). Different band intensities were found in 4 repeated samples of HSC-4 cell line ranging from medium to thin bands. Results of that in NHOM $(n=14)$ were more variably shown. Strong protein bands of the p73 showed in 8 out of 14 NHOM samples and 5 out of 14 samples were presented as medium bands (Table 1). Overall, expression of the human TERT was relatively lower compared to that of $\mathrm{P} 73$ in both HSC-3 and HSC-4 cell lines. However, when the P73 expression was compared between the two cell lines, the HSC-3 cell line showed relatively higher level of p73 expression compared to HSC-4 cell line. While only 2 out of 14 of NHOM showed medium level of human TERT, all NHOM samples showed strong P73 bands.

\section{DISCUSSION}

The SeeBluePlus2 (Invitrogen) protein molecular weight marker consist of ten protein marker bands and has an ability to estimate protein molecular weight within $3-188 \mathrm{kDa}$ on SDS PAGE gel after comassie blue staining. However, some problems were found when determining the human TERT molecular weight using this protein marker. Based on this protein marker, the human TERT which had $127 \mathrm{kDa}$ molecular weight should be located within $117 \mathrm{kDa}$ and $137 \mathrm{kDa}$ protein bands. It was difficult to visually observe the human TERT bands between those very close protein markers with such a considerable molecular weight disparity. The determination was further need the usage of Quantity One (BioRad) Program. The suspected human TERT presented in HSC-3 and HSC-4 cell lines was consistent with many literatures that most of cancer cells had a telomerase activity that affected by hTERT gene. ${ }^{6} \mathrm{Mu}-$ 

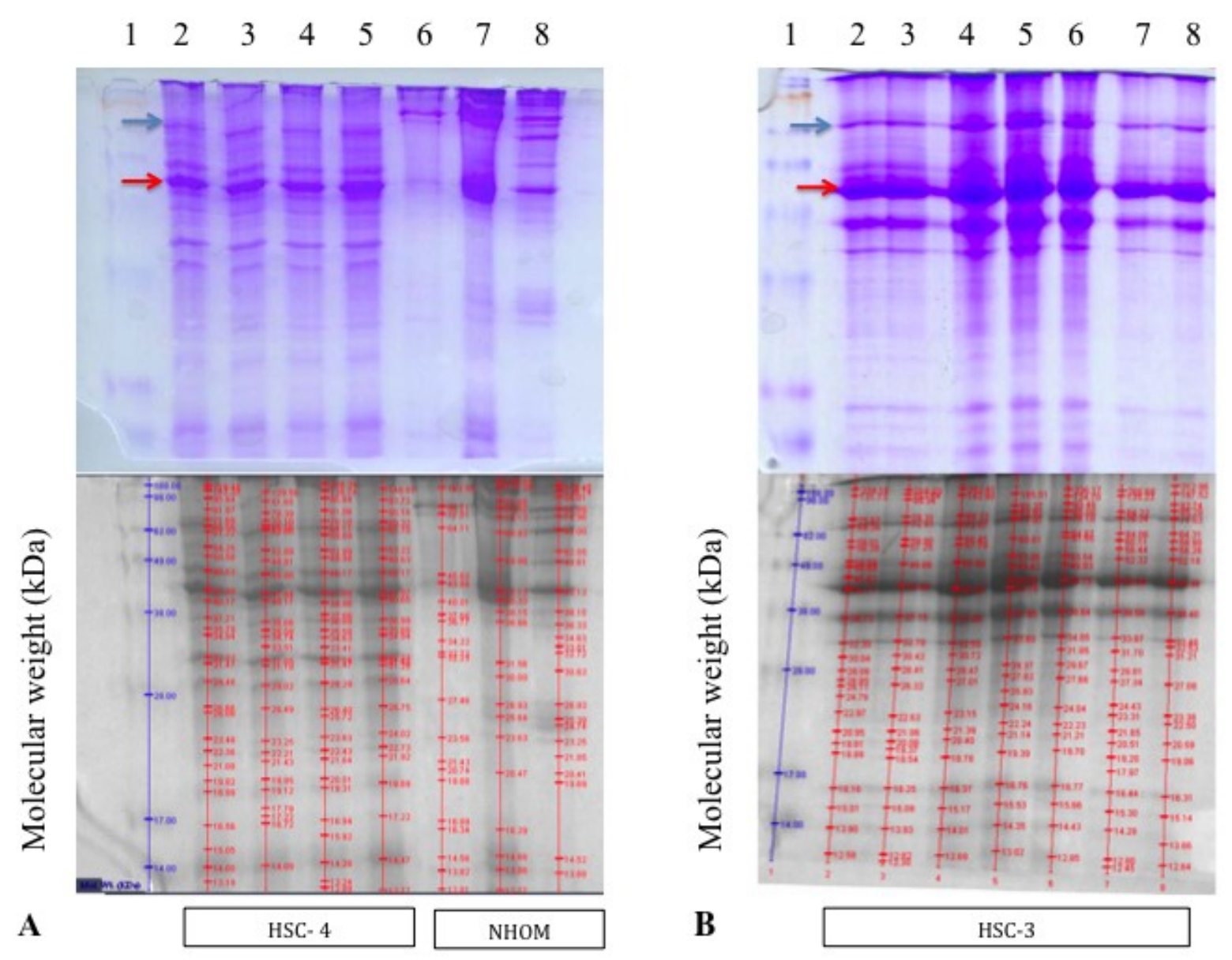

Figure 2. SDS PAGE gel (upper panel) and semi quantitave analysis of bands intensity using Gel Doc 2000 (lower panel). Approximate location of human TERT at $127 \mathrm{kDa}$ (grey arrow) and P73 at 90kDa (black arrow), A. (1) Molecular weight marker (kDa) SeeBluePlus2 (Invitrogen), (2)-(5) HSC-4, (6)-(8) NHOM samples. B. (1) Molecular weight marker (kDa) SeeBluePlus2 (Invitrogen), (2)-(8) HSC-3.

Table 1. Presence and level of expression of P73 protein on SDS PAGE on HCS-3, HSC-4 and NHOM samples

\begin{tabular}{cccc}
\hline No & Sample & Presence of P73 & Expression level of P73* \\
\hline 1 & HSC 3 & + & Thick \\
2 & HSC 3 & + & Thick \\
3 & HSC 3 & + & Thick \\
4 & HSC 3 & + & Thick \\
5 & HSC 3 & + & Thick \\
6 & HSC 4 & + & Medium \\
7 & HSC 4 & + & Thin \\
8 & HSC 4 & + & Medium \\
10 & NHOM 2 & + & Medium \\
11 & NHOM 3 & + & Thin \\
12 & NHOM 4 & + & Medium \\
14 & NHOM 8 & + & Thick \\
15 & NHOM 9 & + & Medium \\
16 & NHOM 10 & + & Medium \\
17 & NHOM 11 & + & Thick \\
19 & NHOM 16 & + & Thick \\
20 & NHOM 17 & + & Thick \\
21 & NHOM 18 & + & Thick \\
22 & NHOM 19 & + & Thick \\
24 & NHOM 21 & + & Medium \\
25 & NHOM 25 & + & Thick \\
26 & NHOM 27 & + & Thick \\
\hline
\end{tabular}

* Based on thickness of band on SDS PAGE 
tation in p53 gene causing mutant form of p53 could not run its normal function as human TERT suppressor. ${ }^{7}$ The HSC-3 and HSC-4 cell lines were known as a p53 mutated cancer cells. Unlike cancer cells, telomerase activity is usually not presents in normal somatic cells. The presence of human TERT expression in normal human oral mucosa used in this research was probably because of the occurrence of keratinocyte and hematopoietic cells presented in blood. ${ }^{14}$ Keratinocyte cell was the main cell found in gingival tissues, meanwhile hematopoietic cell is a cell isolated from blood or bone marrow that could renews itself and differentiates into many variable cells. $^{15,16}$

Based on the literature, each proteins and isoforms from P73 expressed at different levels, depends on the tissue types and the development stages. ${ }^{17,18}$ The p73 expression in cancer was very variable and some cell lines and primary tumor cells expressed P73 at the easily detected level. ${ }^{18}$ According to the data obtained, the P73 was detected at all HSC-3 and HSC- 4 cell lines. The P73 was also detected in most of the human oral mucosal samples observed. The intensity of the P73 expression was determined based on protein bands density approximately at $90 \mathrm{kDa}$ molecular weight presented at SDS PAGE. The expression of P73 exhibits an active gen activity. Observation on SDS PAGE gel showed that HSC -3 had a higher P73 expression than HSC-4. The HSC-3 and HSC-4 cell lines have different property in p53 mutation. In HSC-3, there is the insertion of 4 base pair TAAG at codon 305-306 and has a SNP 72P (coding proline) and the cell line does not produce P53. Meanwhile in HSC-4, there is missense mutation at codon 248 and had SNP 72R (coding arginine) and the cell line produces mutant $\mathrm{p} 53 .^{18-20}$ The result of this study showed higher level of P73 in HSC-3 than in HSC-4 cell lines. It might be resulted from the fact that there is no p53 in HSC-3, therefore it was postulated that P73, which had a proapoptosis activity, is expressed in higher level. The
P73 protein might act to compensate the function of p53 that is reduced or lost in the cell line. These results might be consistent with the fact that HSC-4 had a single nucleotide polymorphism at codon $72 \mathrm{R}$ that encodes arginine. Consequently, p53 mutant is more strongly bind to and inactivate $\mathrm{p} 73$. However, the complexity of p73 need to be considered further, since p73 was known to produce some protein isoforms by alternative splicing mechanism. One of P73 products is anti apoptosis molecule. Since p73 is proand anti-apoptosis proteins concurrently, those relative expression of both proteins should be put in importance while observing the gene expression at protein level. There are some tumors that show high P73 expression and there are some tumors that exhibit low P73 expression. This is possible as each of P73 isoforms had a different effect. This research did not separate P73 with a reagent that could distinctly separate TA and $\mathrm{N}$ form of P73. ${ }^{19,20}$

In HSC-3 and HSC-4 cell lines, there are p53 mutations exist with different properties. In HSC-3, the mutation form is the insertion of 4 base pair TAAG at codon 305-306 and has a SNP 72P (coding proline) and not producing p53 protein. Meanwhile HSC-4 the mutation form is the missense mutation at codon 248 and had SNP 72R (coding arginine) and producing mutant $\mathrm{p} 53$ protein. $^{20}$

With in situ RT-PCR, hTERT expression was not seen in normal epithelium or mild dysplasia, but it was detected at moderate dyplasia with higher level of histopathology, severe dysplasia, and invasive carcinoma. This indicate that the increase of telomerase expression is found in oral carcinogenesis and support telomerase roles in human oral cancer development. $^{22}$ The amount of hTERT transcription quantity detected at normal tissue speciments was caused by the presence of oral keratinocyte and hematopoietic cells that exhibits a constant telomerase activity to undergo cell replication, differentiation and regeneration. ${ }^{15,22,23}$

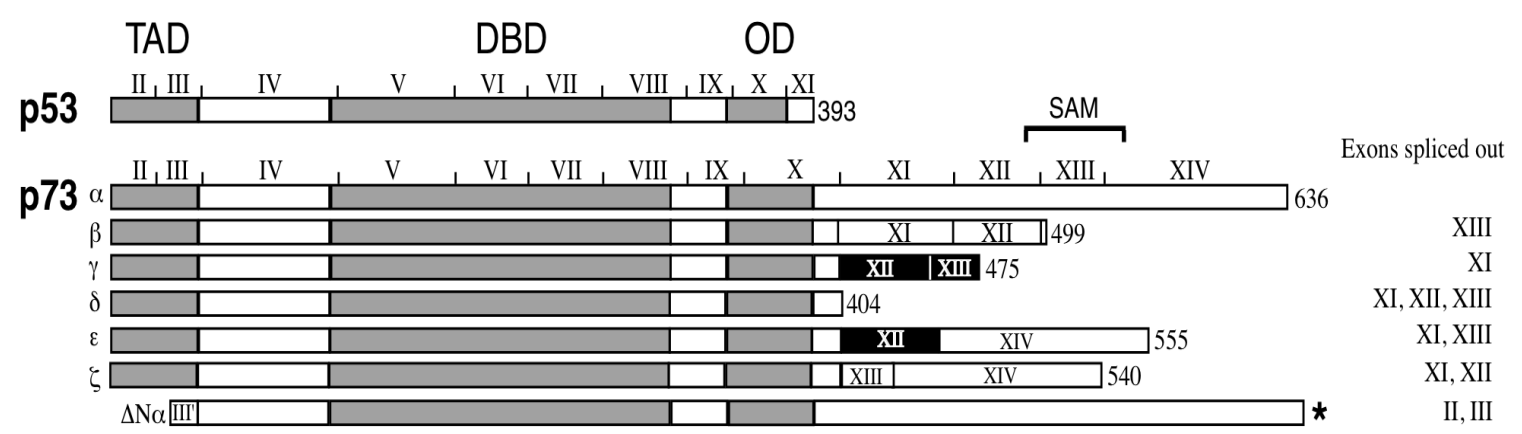

Figure 3. Schematic diagram of exon structure of p53 and p73. The region of transactivation domain (TAD), DNAbinding domain (DBD) and the oligomerization domain (OD) are shown in grey. Sterile alpha motif (SAM). Numbers of exons are indicated in Roman letters above the full length protein. The number of exon spliced out in each isoform are shown on the right. $(*)$ indicate the isoform that only described in mouse. ${ }^{17}$ 
p53 was very low expressed at epithelial cell, while P73 was expressed a lot at epithelial tissues which are the location of carcinoma growth. This demonstrates that P73 had a tissue specialty towards epithelial solid tumor rather than P53. ${ }^{15,22,23}$ Furthermore, P73 has a role in malignant transformation at squamous cell carcinoma. Functional loss of P73 was related with squamous cell carcinoma. This is because a transformation from initial into malignant stage at mice models was followed by an almost total sporadic loss in p73 mRNA and its protein expression. ${ }^{12}$

\section{CONCLUSION}

It can be concluded that the human TERT found in HSC- 3 and HSC-4 cell lines is related to the condition of p53 mutation. In normal human oral mucosa, human TERT is likely exposed from actively differentiating and regenerating cells of the tissues. Based on the density of protein bands on SDS PAGE, the P73 expression in HSC-3 was higher than in HSC-4. This might be influenced by the different $\mathrm{p} 53$ protein level at those cell lines and the interaction strength between $\mathrm{p} 73$ and mutant $\mathrm{p} 53$ with polymorphism at codon 72 . The HSC-4 cell line which is known as p53 mutant with arginine at 72 residue is more strongly bind to and inactivate p73. Most of the normal human oral mucosa samples showed bold P73 bands that easily observed visually. The expression pattern demonstrated is conformed the theory that P73 had a specific location of action at the epithelial tissues. Further study need to be done to get deeper insight on the specific isofroms of P73 that plays role in the findings of the current study.

\section{REFERENCES}

1. Mao L, Hong WK, Papadimitrakopoulou VA. Focus on head and neck cancer. Cancer Cell. 2004;5:311-6.

2. Toh WH, Kyo S, Sabapathy K. Relief of p53 mediated telomerase suppression by $\mathrm{p} 73$. J Biol Chem. 2005;280:17329-38.

3. Saeboe-Larssen S, Fossberg E, Gaudernack G. Characterization of novel alternative splicing sites in human telomerase reverse transcriptase (hTERT): analysis of expression and mutual correlation in mRNA isoforms from normal and tumour tissues. BMC Mol Biol. 2006;7:26.

4. Xu D, Wang Q, Gruber A, Bjorkholm M, et al. Down regulation of telomerase reverse transcriptase mRNA expression by wild type p53 in human tumor cells. Oncogene. 2000;19:5123-33.

5. Cong YS, Wen J, Bacchetti S. The human telomerase catalytic subunit hTERT: organization of the gene and characterization of the promoter.
Hum Mol Genet. 1999;8:137-42.

6. Wu J, Wei LX. Telomere and telomerase in oncology. Cell Res. 2002;12:1-7.

7. Horikawa I, Barret JC. Transcriptional regulation of the telomerase hTERT gene as a target for cellular and viral oncogenic mechanisms. Carcinogenesis. 2003;24:1167-76.

8. Kaelin WG Jr. The p53 gene family. Oncogene. 1999;18:7701-5.

9. Zaika AI, Slade N, Erster SH, Sansome S, et al. Delta NP73, a dominant-negative inhibitor of wild-type p53 and TAP73, is up-regulated in human tumors. J Exp Med. 2002;196:765-80.

10. Johnson J, Lagowski J, Sundberg A, Lawson S, et al. p73 Loss trigger conversion to squamous cell carcinoma reversible upon reconstitution with TAP73 $\alpha$. Cancer Res. 2007;67:7723-30.

11. Nakagawara, T. p73, a sophisticated p53 family member in the cancer world. Cancer Sci. 2005;96:729-37.

12. Irwin MS, Miller FD. p73: regulator in cancer and neural development. Cell Death Differ. 2004;11:S17-S22.

13. Campisi J. Senescent cells, tumor suppression, and organismal aging: good citizens, bad neighbors. Cell Res. 2005;120:513-22.

14. Kim HR, Christensen R, Park NH, Sapp P, et al. Elevated expression of hTERT is associated with dysplastic cell transformation during human oral carcinogenesis in situ. Clin Cancer Res. 2001;7:3079-86.

15. Fujimoto R, Kamata N, Yokoyama K, Ueda N, Satomura K, Hayashi E, Nagayama M: Expression of telomerase components in oral keratinocytes and squamous cell carcinomas. Oral Oncol. 2001;37:132-40

16. Bethesda M. Hematopoietic Stem Cells. National Institutes of Health, U.S. Department of Health and Human Services. [Online] 2006. [Cited: December 15, 2008.]

17. Stiewe T, Putzer B: Role of p73 in malignancy: tumor suppressor or oncogene? Cell Death Differ. 2002;9:237-45.

18. Beitzinger M, Oswald C, Beinoraviciute-Kellner R, Stiewe T: Regulation of telomerase activity by the p53 family member p73. Oncogene. 2006;25:813-26.

19. Stiewe T, Tuve S, Peter M, Tannapfel A, et al. Quantitative TP73 transcript analysis in hepatocellular carcinomas. Clin Cancer Res. 2004; 10:626-33.

20. Flores ER, Sengupta S, Miller JB, Newman JJ, et al. Tumor predisposition in mice mutant for p63 and $\mathrm{p} 73$ :evidence for broader tumor suppressor functions for the p53 family. Cancer Cell. 2005;7:363-73.

21. Luzar B, Poljak M, Gale N. Telomerase catalytic subunit in laryngeal carcinogenesis. Mod Pathol. 2005;18:406-11. 
22. Kumar S, Zain R, Ismail S, Cheong S: Human telomerase reverse transcriptase expression in oral carcinogenesis-a preliminary report. J Exp Clin Cancer Res. 2005;24:639-46.

23. Kamiya Y, Ohshima T. The individual cell properties of oral squamous cell carcinoma and p53 tumor suppressore gene mutation. Oral Sci Int. 2005;2:104-17. 